to genetics, of course, nor even to biology. The same reasons can be urged for oxygene as for pangene. Scores of terms have been based on the same root, $\gamma \epsilon v$, but hitherto with a short vowel, as in the Greek. Some philologists add a letter in forming such a word as clone, where the original Greek vowel is long, but this has nothing to do with Dr. Shull's "general law of English philology" that would lengthen short vowels to enable Greek derivatives to be pronounced with a German accent. In this case Johannsen's correct word "gen" was displaced by a linguistic monstrosity, "gene," because the latter was supposed to sound more like German, and because "the German word 'Pangen' better expresses the meaning involved than does the English word "pangen." The new final "e" symbolizes the magically improved connotation acquired by Darwin's word pangen in passing from English into the hallowed precincts of the German language. It replaces the italics, capitals and quotation marks otherwise required to differentiate the more expressive German "Pangen" from the ordinary English "pangen." The mistake, as now appears, was not a merely casual adoption of the German plural "Gene" as an English singular, but a deliberate substitution of an erroneous new singular "gene," anomalous alike in German, Greek or English. Dr. Shull does not state when, where or by whom this change from "gen" into "gene" was determined, but these details are of no importance now that the method has been explained. It would have been easier to bestow "gene" and "pangene" on the French, who use "oxygène" and a whole class of similar terms, but the German derivation is more ingenious.

Regarding the phenotypes, little need be said. Dr. Shull reasserts the reality of phenotypes, and even insists with italics that "statistical investigation may discover, measure and describe phenotypes." But if it be true that "phenotypes and genotypes exist among Mendelian hybrids," or elsewhere in nature, they must be the names of classes or groups of animal or plant individuals distin- guished by the possession of certain characters or gens. Such group names are usually considered as collectives, but Dr. Shull maintains that phenotypes "must always be abstractions." Evidently the new science of genetics is to have an original system of metaphysics as well as of philology.

$$
\begin{aligned}
& \text { BARD, CALIFORNIA, } \\
& \text { June } 17,1912
\end{aligned}
$$

PROPOSITIONS FOR CHANGES IN THE INTERNATIONAL CODE OF ZOOLOGICAL NOMENCLATURE

AtTentron of zoologists is invited to the rule that all propositions for changes to the International Code must be in the hands of the Commission at least one year before the meeting of the International Congress.

Formal notice of the exact date of meeting has not yet reached me, but I hope to have my first report to the Commission prepared for mailing not later than September 1. About that date I shall also send to Science and to the Zoologischer Anzeiger a complete list of the propositions that have been sent to me.

It is a great satisfaction to the Commission to note the increased and more general interest exhibited by zoologists in nomenclatorial matters, and I take the liberty of repeating a statement made on several former occasions, namely, that the Commission welcomes most heartily correspondence and suggestions from all zoologists.

$$
\begin{gathered}
\text { C. W. STILEs, } \\
\text { Secretary, International Commission } \\
\text { on Zoological Nomenclature }
\end{gathered}
$$

\section{THE PEI YANG UNIVERSITY}

To the Editor of Science: A note by Consul General S. S. Knabenshue, of Tientsin, China, regarding vacancies in the staff of the Pei Yang University, of that city, published in Daily Consular and Trade Reports of July 8 , seems likely to deluge me with inquiries and applications, and I would be glad if you would aid me in forestalling them by publishing this statement. There are no vacancies in the staff of the Pei Yang University at 
present, Dr. George I. Adams, of the United States Geological Survey, having been recently appointed to the chair of geology and mining, and Dr. H. V. Fuller, of Zürich University, to the chair of chemistry. Next year the professorship of railway engineering will be vacant, but only properly qualified persons should apply, as the university, though small, maintains a high standard and the salary offered is sufficient to command the services of able and experienced men. I have received many applications for positions which do not exist, and beg to point out that, as stated in ScIEnce, March 1, 1912, the professorships now filled by foreigners are: law, two; economics and history, one; chemistry, one; geology and mining, one; metallurgy, one; civil engineering, two; mechanical engineering, one; railroad engineering, one. As stated above, none of these are now vacant. There are no professorships in mathematics, physics, biology, zoology, botany, agriculture, pedagogy and kindred subjects, nor are any likely to be created.

\section{Thomas T. READ}

San francisco, Cal.

\section{SCIENTIFIC BOOKS}

Technology and Industrial Efficiency. A Series of Papers Presented at the Congress of Technology, opened in Boston, Mass., April 10, 1911, in Celebration of the Fiftieth Anniversary of the Granting of a Charter to the Massachusetts Institute of Technology. McGraw-Hill Book Company. 1911. Pp. 486.

This volume of papers, covering a large variety of topics in applied science, derives its interest possibly as much from the occasion which has called it forth, as from its contents. The charter of the Massachusetts Institute of Technology was signed by Governor Andrew on April 10, 1861. The fiftieth anniversary of this event was taken advantage of for the inauguration of a congress of technology which lasted through several days, and to which the public was invited, to listen to the reading of papers contributed by graduates and professors of the institute.
The occasion was thus, in some degree, a celebration of the fiftieth anniversary of the institute, and a demonstration, so far as it was needed, of the prominent position in applied science which had been won by it and by its graduates.

It is an interesting question, in how short a time may an institution of learning, without substantial state aid or endowment, dependent almost wholly upon its own resources and the merits of what it has to offer, attain to a commanding position among institutions of learning? The lesson which has been taught by the institute is, in this respect, most instructive. Here is an institution which, in the short space of considerably less than fifty years, has become one of the leading institutions of its kind in this country or in the world, and it has attained this position solely by its own merits and exertions, with a small endowment, with little aid from the stateuntil within a very few years-and obliged to depend, therefore, for its maintenance and progress upon the tuition fees from students and such scattering gifts as it might receive from time to time. This position of leadership has already been held by the institute for at least fifteen or twenty years, so that from the date of the first small beginnings, when the classes met in hired quarters in the business section of the city of Boston, the school has developed in a third of a century into a position of unquestioned leadership.

Under these conditions it is not unnatural that its graduates, faculty and corporation should take advantage of the fiftieth anniversary of its birth to celebrate the progress which has been made. The papers presented at the congress have been edited and collected in the volume referred to above.

These papers, covering, as they do, the whole field of applied science, differ widely in character and subject. There are but few on any one topic, and the specialist will find but little in the volume to enlarge his detailed knowledge. Nevertheless, the papers have been kept somewhat non-technical in form and designed to be of general interest to the applied scientist, and this object has been ad- 